\title{
Analysis of Prospective Physics Teachers' Ability to Design Experiments in University of West Sulawesi
}

\author{
Mutmainna \\ Fakultas Keguruan dan Ilmu Pendidikan, Universitas Sulawesi Barat \\ Corresponding Author Email: mutmainna kadir@unsulbar.ac.id
}

\begin{abstract}
Article History
Received: April 2021

Accepted: May 2021

Published: June 2021

\section{Key Words}

Physics learning;

the ability to design

experiments;

prospective physics

teachers;

design and analysis of secondary school physics practicum course
\end{abstract}

How to cite this article?

\begin{abstract}
Physics learning is identified to hand-on activities and built through scientific activities. Identification of students' understanding regarding physics theories and the ability to design physics experiments was allegedly very important to support the output profile of Physics Education Study Program in the form of professional educators. This study aimed to determine (1) the profile of prospective physics teacher's ability to design experiments at the University of West Sulawesi; (2) the category of prospective physics teacher's ability to design experiments; and (3) learning evaluation of Design and Analysis course of Secondary School Physics Practicum. This research is a descriptive exploratory study, where data is collected using an open-ended observation sheet with seven aspects of the ability to design experiment. Descriptive statistics were used to analyze research data obtained from 40 research subjects. The results showed that (1) overall, the prospective physics teacher's ability to design experiments was in the range $1.96-2.51$; (2) the prospective physics teacher's ability to design experiments at the University of West Sulawesi was in the quite good and very good categories; (3) the presentation skill was an aspect that needs to be improved, while the theoretical basis understanding was the most prominent aspect based on the learning evaluation results of Design and Analysis course of Secondary School Physics Practicum
\end{abstract}

Mutmainna, M. (2021). Analysis of Prospective Physics Teachers' Ability to Design Experiments in University of West Sulawesi. Lensa: Jurnal Kependidikan Fisika, 9(1), 1-9. doi:https://doi.org/10.33394/j-1kf.v9i1.3446

\section{INTRODUCTION}

Students' knowledge of the concepts and development of science based on natural phenomena experienced in everyday life, basically has been owned before being taught formally. Experts conclude that children learn science through the concept of what they create / construct themselves (Wisudawati, 2014).

Furthermore, Wisudawati (2014) explains that one of the challenges of learning science in schools is providing access to physical experiences and helping students to understand science concepts independently, as well as introducing science concepts that have been mutually agreed upon by the science community. In other words, the science learning process focuses on the research process and problem solving. In line with this statement, Fitriani et al. (2016) stated that students have an important role in science learning activities. Learning activities must be designed to facilitate students in building various kinds of knowledge and skills, so that science learning is not only limited to memorizing knowledge.

Physics as a branch of natural science was a process of natural events study based on facts, concepts, and laws that have been studied by experts through a scientific approach. Some of the physical characteristics are (1) the object under study was a real object based 
on its behavior and physicality; (2) observations and research were carried out deliberately; (3) systematic research; (4) think logically and consistently; (5) objective studies, and (6) applicable laws generated through various experiments (ADIP, 2016).

Experiments as a characteristic of Natural Science have a number of roles, particularly in learning physics. Experimental activities can be carried out through the implementation of experimental methods in learning. According to Arifin (2003), the advantages of using an experimental or practicum method are as follows: (1) can describe a concrete situation about an event; (2) students can observe the process; (3) students can develop inquiry skills; (4) students can develop a scientific attitude; and (5) help teachers to achieve learning goals more effectively and efficiently.

Teacher has important roles in optimizing physics learning through experimental activities. Teachers need to be supported with various abilities so that they can carry out their duties and functions as teaching staff optimally. Facilitator, responsive to developments in information technology, manager, demonstrator, motivator, and evaluator are some of the professional duties of a teacher (Sanjaya, 2014). Therefore, in understanding physics concepts through experimental activities, prospective physics teacher should have adequate abilities before becoming a teacher in order to carry out their role optimally.

The Middle School Physics Practicum Design and Analysis course is one of the compulsory subjects listed in the curriculum of the Physics Education Study Program, FKIP, Universitas Sulawesi Barat. Some of the Subject Learning Outcomes (CPMK) formulated in this course emphasize the ability of prospective physics teachers to examine and analyze the nature and meaning of high school physics practicum activities. In this course, prospective physics teachers are expected to be able to: identify practicum components in each experimental theme that apply according to National education standards, design and analyze secondary school physics practicum, design Student Worksheet products (LKPD) based on the results of designed experimental analysis. So that through this course, prospective physics teachers are expected to be skilled in supervising physics practicum activities at the high school level, especially when they become a teacher.

Design and Analysis of Secondary School Physics Practicum activities are carried out through the application of the open inquiry experimental learning method which is carried out by prospective physics teachers independently. Open inquiry according to Sarwi (2010) is an experiment conducted by describing the problem by the lecturer, then prospective physics teachers are given the opportunity to identify and solve the problem. The implementation of the open inquiry learning method in this course allows an investigation to determine the prospective physics teachers' profile of the ability to design experiments, the category of the prospective physics teachers' ability to design experiments and to evaluate the preparation of the RPS in the next academic year for lecturers who teach the subject. In addition, the implementation of open inquiry encourages students to have a high sense of curiosity so that the constructed concept is attached and not easily lost (Jumini, 2013).

Wahyudi, et al. (2017) through community service activities as an implementation of the results of the research conducted stated that the design of inquiry-based science experiments can be carried out in several stages, namely (1) having a subject matter; (2) set the objective of the experiment; (3) compiling an outline of the experimental steps, and (4) planning the technical implementation of the practicum. The results showed that the teachers had increased their abilities in the science experiment. On the other hand, Heriansyah (2017) who modified the experimental design components according to Sarwi 
(2010) stated that there were seven aspects of assessing the ability to design experiments based on the scores obtained based on group assessments, namely (1) determining the type of experiment; (2) determine the purpose of the experiment; (3) understand the theoretical basis; (4) identifying tools and materials and arranging tools; (5) formulating procedures and implementing them; (6) compile experimental reports; and (7) presentation skills. The results of this study indicate several things that need to be improved, namely increasing the ability in the aspect of determining the type of experiment and aspects of preparing experimental reports. The student's ability to design experiments which is quite prominent is in the aspect of identifying tools / materials and assembling tools and formulating procedures and implementing experiments.

Based on the description of the characteristics of the implementation of lecture activities as well as the results of the relevant studies previously described, it is important to conduct research by modifying some parts of previous studies. This can be done through the assessment of the profile of the prospective physics teachers' ability to design experiments by measuring individual abilities, analyzing data to obtain an overview of the category of the prospective physics teachers' ability to design experiments and follow up on the results of research as evaluation material for lecturers who teach the courses. This study aimed to determine (1) the profile of prospective physics teacher's ability to design experiments at the University of West Sulawesi; (2) the category of prospective physics teacher's ability to design experiments; and (3) learning evaluation of Design and Analysis course of Secondary School Physics Practicum.

\section{METHOD}

This research is a descriptive-exploratory study which aims to describe the state of a phenomenon but only explains certain research variables without comparing them with other research variables (not testing the hypothesis) (Arikunto, 2006).

The profile of the ability to design experiments in prospective physics teacher was obtained through the results of data analysis of the ability to design experiments using seven modified assessment indicators from Sarwi (2010). The category of ability to design experiments for prospective physics teacher students at the University of West Sulawesi was obtained through data analysis on the ability to design experiments using descriptive statistics which were further categorized based on the scoring criteria of the reference sources used (see Table 2).

The subjects used in this study were students of the 2016 Physics Education Study Program, totaling 40 students in two classes of the even semester of the 2018/2019 Academic Year. This research was conducted for 3 months and was divided into three stages of research. The first stage is preparation in the form of problem formulation and research objectives, preparation of research instruments (rubric for assessing the ability to design experiments) according to the literature used as a reference and Semester Learning Plan (RPS). The second stage is the implementation stage, in which students in two classes who are research subjects are divided into four groups based on different experimental themes. The themes of the experiment consisted of (1) mechanics; (2) Optics; (3) Magnetic Electricity; (4) Waves and Thermodynamics. The activities carried out by students begin by identifying tools / components that allow them to be used in designing experiments to the finalization stage of the LKPD which contains experimental designs based on the given theme.

Open inquiry is applied in the process of designing and analyzing physics experiments at the high school level. The final part of this activity, each member of the group presents the results of the experiment which was carried out in front of the lecturer 
who teaches the course. The final stage of the research activity is the data analysis stage. Data on the profile of prospective physics teachers' ability to design experiments at the University of West Sulawesi were obtained using a research instrument in the form of a scientific work assessment. Table 1 shows the format for the intended scientific work assessment.

Table 1. Scientific work assessment of the ability to design experiments (modification from Sarwi, 2010).

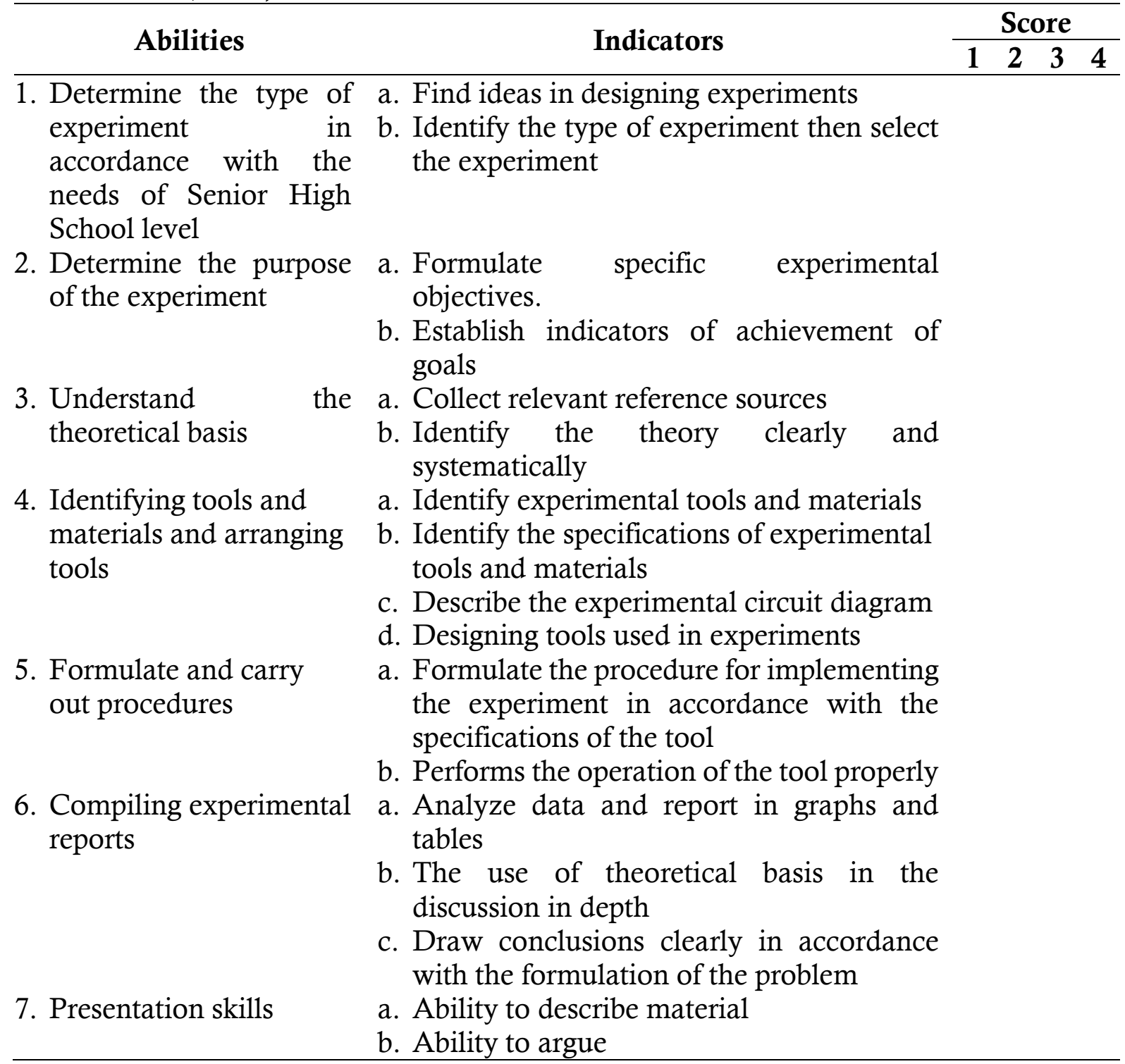

Note:

Score 0: absent or do not do / write down.

Score 1: less sharp / insufficient or slightly weak in relation.

Score 2: sufficiently complete / sufficiently appropriate / deep enough.

Score 3: clear / complete / deep

The scoring criteria for the ability to design experiments can be seen in Table 2 below.

Table 2. The scoring criteria (modified from Sarwi, 2010)

\begin{tabular}{ccc}
\hline No. & Score & Criteria \\
\hline 1 & $0-1.00$ & Not good \\
2 & $1.01-2.00$ & Good enough \\
3 & $2.01-3.00$ & Very good \\
\hline
\end{tabular}




\section{RESULTS AND DISCUSSION}

One of the achievements of the Middle School Physics Practicum Design and Analysis course is that students are proficient in designing experiments in physics subjects at the SMA / MA level in accordance with the demands of the applicable curriculum. In the implementation, students are asked to make an experimental design based on their respective experimental themes. The stages carried out by each group are presented in Table 3.

Table 3. Stages of Designing Experiment Activities

\begin{tabular}{|c|c|c|}
\hline No & Stages & Description \\
\hline 1 & $\begin{array}{l}\text { Review the curriculum by } \\
\text { identifying the formulation of Basic } \\
\text { Competencies according to the } \\
\text { theme of the experiment. }\end{array}$ & $\begin{array}{l}\text { At this stage, each group reviews the physics } \\
\text { curriculum by identifying the formulation of Basic } \\
\text { Competence (KD) according to the theme of their } \\
\text { respective experiments. The reference source used } \\
\text { refers to Permendikbud Number } 24 \text { of } 2016 \text {. }\end{array}$ \\
\hline 2 & $\begin{array}{l}\text { Identification of components / tools } \\
\text { / materials / experiments }\end{array}$ & $\begin{array}{l}\text { The identification of experimental components is } \\
\text { carried out to find out what components / tools } \\
\text { might be used in designing an experiment based on } \\
\text { the theme of each experiment. The practicum } \\
\text { components identified are those that are in } \\
\text { accordance with the demands of the applicable } \\
\text { curriculum and are commonly used in schools, } \\
\text { especially at the SMA / MA level. }\end{array}$ \\
\hline 3 & $\begin{array}{l}\text { Determination of the title and } \\
\text { preparation of LKPD }\end{array}$ & $\begin{array}{l}\text { At this stage each member of the group is assigned } \\
\text { to compile at least } 1 \text { experimental design through } \\
\text { the preparation of LKPD. Each group member is } \\
\text { asked to collect the results of the work and discuss } \\
\text { these results together in the group. The number of } \\
\text { experimental designs proposed by each group is at } \\
\text { least seven experimental designs. }\end{array}$ \\
\hline 4 & $\begin{array}{l}\text { Trial of experimental design based } \\
\text { on the prepared LKPD }\end{array}$ & $\begin{array}{l}\text { At this stage, the results of the discussion from the } \\
\text { previously agreed stages are followed up by } \\
\text { conducting the experimental design trial. Each } \\
\text { group collects data and records important things. }\end{array}$ \\
\hline 5 & rimental design & $\begin{array}{l}\text { The evaluation results of the experimental design } \\
\text { trial were followed up by improving the contents of } \\
\text { the LKPD }\end{array}$ \\
\hline 6 & Finalize the experimental design & $\begin{array}{l}\text { Finalization is carried out based on produced an } \\
\text { agreement in the previous stage (revised } \\
\text { experimental design). }\end{array}$ \\
\hline 7 & Experimental design presentation & $\begin{array}{l}\text { Presentations are made by each group member in } \\
\text { front of the lecturer who teaches courses to get } \\
\text { responses to the experimental design that has been } \\
\text { finalized, as well as a form of individual } \\
\text { assessment. }\end{array}$ \\
\hline
\end{tabular}

Data from the results of the profile of the prospective physics teachers' ability to design experiments at the University of West Sulawesi were obtained from the assessment of aspects and indicators in Table 1. The data can be seen in Figure 1. 


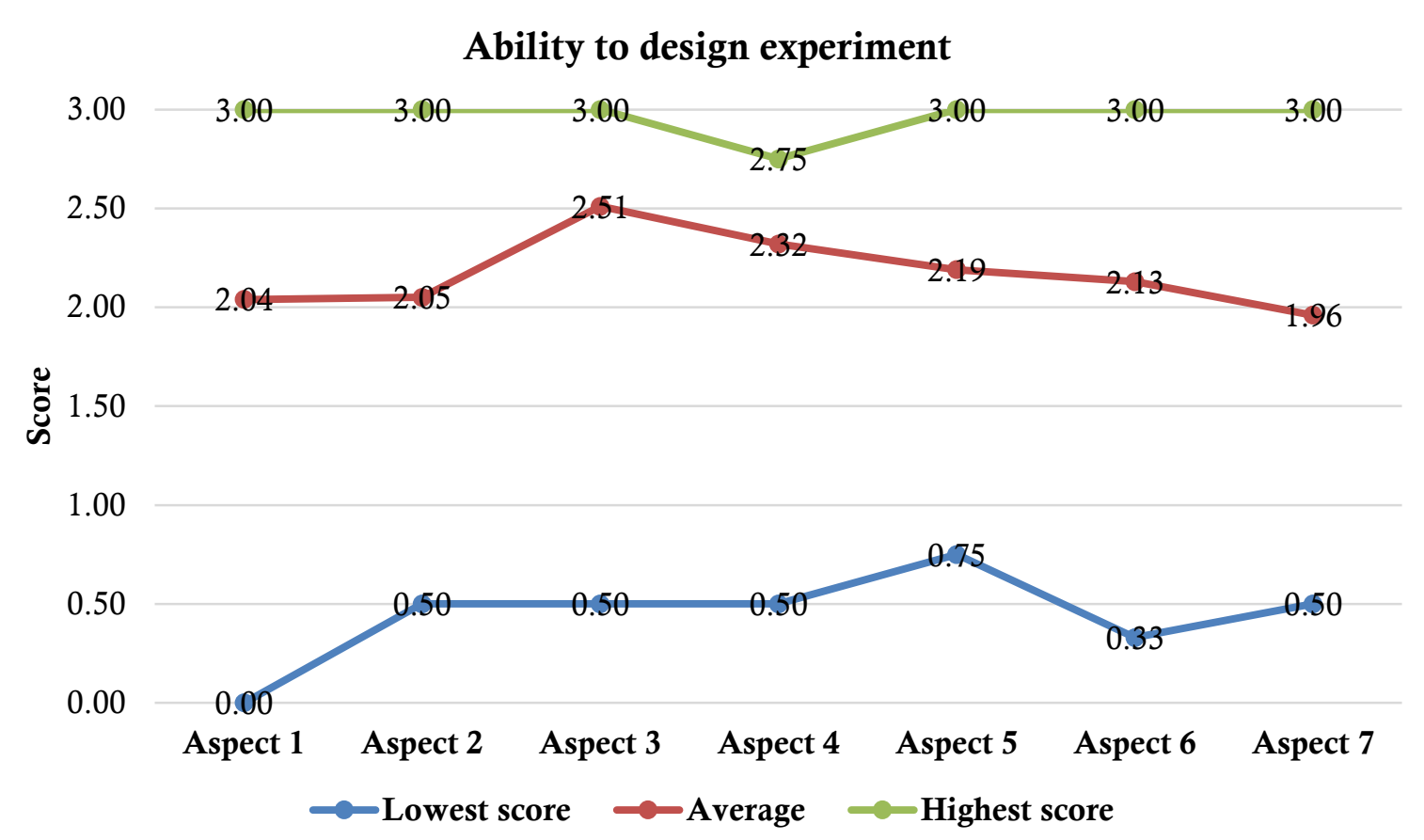

Figure 1. Research data on the prospective physics teacher ability to design experiments

Note:

Aspect 1: Determine the type of experiment in accordance with the needs of Senior High School level

Aspect 2: Determine the purpose of the experiment

Aspect 3: Understand the theoretical basis

Aspect 4: Identifying the tools and materials and assembling the tools

Aspect 5: Formulating procedures and implementing them

Aspect 6: Compiling experimental reports

Aspect 7: Presentation skills

The data contained in Figure 1 is a data distribution summarized from 40 students who present the lowest score, the average score, of the maximum score from each aspect. Based on these data, it was found that the research results in aspect 1 (determining the type of experiment according to the needs of Senior High School level) is an aspect with the lowest score of students is 0.00 and the highest score is 3.00. In this section students are required to be able to identify the expected achievements of students according to the applicable curriculum so that the appropriate type of experiment can be determined. At advanced levels such as SMP \& SMA, the portion of scientific mastery is more optimized. So that elementary and junior high and high school teachers have different focuses in providing lessons. This results in demands for different mastery of competencies that teachers in SD, SMP and SMA (Wahyudi, 2017) must have.

Based on the results of the observations obtained, there were a number of students who included pure experimental designs from designs available from other sources without making revisions or adding ideas to their own copyright works. However, in general, it is obtained an average score of 2.04 which is in the very good category. Student Ability Assessment Designing experiments in the aspect of determining the type of experiment according to the needs of the high school level is influenced by the ability to find ideas in designing experiments and the ability to distinguish between demonstrations 
and experiments (Heriansyah, 2017). There is a difference between demonstration and experiment. The demonstration emphasizes the observation of physical phenomena without having to obtain observational data and is generally carried out by the teacher in front of students. While experiments are activities that provide opportunities for students to experience or do it themselves and there are clear work procedures at each step of the activity (Abdullah, 2016).

In aspect 2 (determining the objective of the experiment) the lowest score for students is 0.50 and the highest score is 3.00 with an average score of 2.05 in the very good category. In general, students are equipped with the ability to formulate the objectives of learning activities in the Physics Learning Curriculum Study course so that the activity of formulating experimental objectives can be passed without many obstacles. Students are given the confidence to formulate experimental objectives independently by asking them to position themselves as physics teachers who want to provide optimal learning to their students.

In aspect 3 (understanding the theoretical basis), the lowest score for students is 0.50 ; the highest score was 3.00; and an average score of 2.51. This aspect is an aspect that has the highest average score of 2.52 which is in the very good category. Based on the results of the observations obtained that most students have been able to meet the criteria / assessment indicators used are able to collect relevant reference sources and are able to identify theories clearly and systematically well.

In aspect 4 (identifying tools and materials and arranging tools), the lowest score for students in this aspect was 0.50 ; the highest score was 2.75; and the average score is 2.32 with very good category. In this aspect, most students have been able to identify the tools and materials used in the designed experiment because the components used are components of the Experiment KIT which has been equipped with a guidebook to identify the names of the content components of the Experiment KIT. In addition, students also have knowledge from the introductory laboratory and basic physics courses. However, there are still a small proportion of students who are in the poor category. This is because the student concerned is still having difficulty recognizing the components of the experiment. Compared to other aspects, the highest score that students can achieve is 2.75 (lower than other aspects).

In aspect 5 (formulating procedures and implementing them), the lowest score for students in this aspect is 0.75 ; the highest score was 3.00; and the average score is 2.19 with very good category. In this aspect, students generally can do well. The shortcomings that often occur in some students, especially those who get poor scores, are carrying out experimental steps without paying attention to the technical data collection, for example the position of the eye on the reading of the measuring instrument, not paying attention to the sensitivity of the measuring instrument so that it causes damage during data retrieval trials and some of it.

In aspect 6 (compiling experimental reports) the lowest score of students in this aspect is 0.33 ; the highest score was 3.00 ; and the average score is 2.13 with very good category. In this aspect, students present the test results of experimental designs that have been made and the presentation of the test result data is presented in the form of tables or graphs. In general, students have been able to do this well. As for the shortcomings that still occur, in some experiments there are groups of students who in analyzing the data do not connect their findings (test results) with existing theories.

In aspect 7 (presentation skills), the lowest score for students in this aspect is 0.50 ; the highest score was 3.00; and an average score of 2.05 with a very good category an average score of 1.96 is good enough. In the 7 th aspect assessment, namely presentation 
skills, most of the students when making presentations in terms of discussing the experimental design (LKPD content) were mostly in the very good category. However, when asked questions to test understanding of the concept, it was found that most students were not able to reason well. Mistakes in aspect 6 also occur in the part where there are some students who have not been able to link the results of the experiment with existing theories so that in this aspect it is deemed necessary to be used as an evaluation of the implementation of learning in the Design and Analysis of Middle School Physics Practicum courses.

If viewed from the category based on the acquisition score, for all aspects the data with the maximum score were obtained in the very good category so that it can be stated that the application of open inquiry can provide information about the profile of the ability to design experiments on prospective physics teacher at the University of West Sulawesi. Open inquiry learning provides students with extensive opportunities to use and develop scientific attitudes and creativity (Jumini, 2017). While Astuti, et al (2015) found that the application of guided experiments is considered more effective in learning activities because it has a clear flow of activities compared to the application of modified free experiments which are considered less effective because participants tend to think on their own so it takes longer. However, if it is related to Ausubel's opinion in Dahar (2006) which states that learning is stated to be meaningful if students independently compile the information learned according to the cognitive structure of each student, the application of open inquiry in this study can be stated as the right step to develop student's creativity particularly in designing experiments.

\section{CONSLUSSION}

The conclusions from the research results obtained through the application of the open inquiry method, namely (1) as a whole, the ability to design experiments for prospective physics teacher students at the University of West Sulawesi is in the range 1.96 - 2.51 ; (2) the ability to design experiments of physics teacher candidate students at the University of West Sulawesi was in the quite good and very good categories; (3) evaluation of learning in the Middle School Physics Practicum Design and Analysis course obtained data from the seven observed aspects, aspects that still need to be improved, namely presentation skills, while the outstanding ability of students is in the aspect of understanding the theoretical basis.

\section{RECOMMENTATION}

Through the results of this study, it is suggested for future researchers to design research activities earlier in order to obtain the most accurate data possible for personal assessments.

\section{ACKNOWLEDGMENTS}

Researchers would like to thank the Education Study Program, FKIP, West Sulawesi University and students of the Class A Physics Education Study Program.

\section{REFERENCES}

Abdullah, S. R. (2016). Demosntrasi dan Eksperimen Fisika. Jakarta: Bumi Aksara.

ADIP, MS (2016) Hakikat dan Ciri-Ciri Fisika Tersedia pada https://fisika.id/2016/11/13/hakikat-dan-ciri-ciri-fisika/ Diakses pada tanggal: 20 September 2020.

Arifin, M. (2003), Common Textbook Strategi Belajar Mengajar Kimia, Jurusan Pendidikan Kimia FPMIPA UPI, Bandung. 
Arikunto, Suharsimi (2006) Prosedur Penelitian Suatu Pendekatan Praktik. Jakarta: PT Rineka Cipta, Jakarta.

Astuti, R, Sunarno, W, Sudarisman, S. (2015). Pembelajaran Ipa dengan Pendekatan Ketrampilan Proses Sains Menggunakan Metode Eksperimen Bebas Termodifikasi dan Eksperimen Terbimbing. Prosiding Seminar Nasional Pendidikan Sains (SNPS) $173-185$.

Dahar, R. W. (2006). Teori-Teori Belajar Dan Pembelajaran. Jakarta: Erlangga.

Fitriani, N. R., Widiyatmoko, A., \& Khusniati, M. (2016). Efektivitas Model CTL Inquiri Terbimbing berbasis Topik Pembahasan Ilmu Kimia dalam Kehidupan Sehari-hari untuk Meningkatkan Hasil Belajar dan Keaktifan Peserta didik. Jurnal Pendidikan IPA Indonesia (JPII), 5(2), 278-283.

Heriansyah, \& Februyanti. (2017). Profil Kemampuan Mahasiswa Calon Guru Fisika dalam Mendesain Eksperimen pada Perkuliahan Eksperimen Fisika 1 Jurnal Ilmu Fisika dan Pembelajarannya 1, 36-41.

Jumini, S. (2013). Penggunaan Metode Open Inquiry untuk memperbaiki kualitas praktikum Elektronika Dasar. Prosiding Seminar Nasional Sains dan Pendidikan Sains VIII, Fakultas Sains dan Matematika, UKSW. 4 (1): 121-132.

Sanjaya, W. (2014). Strategi Pembelajaran Berorientasi Standar Proses Pendidikan. Jakarta: Kencana Prenadamedia Group.

Sarwi, S. K. (2010). Pengembangan Keterampilan Kerja Ilmiah Mahasiswa Calon Guru Fisika Melalui Eksperimen Gelombang Open Inquiry. Jurnal Pendidikan Fisika Indonesia. 6: 115-122.

Wahyudi, E, T \& Handy, D. (2017) Peningkatan Keterampilan Guru Dalam Merancang Percobaan Ipa Berbasis Inkuiri di Kabupaten Bengkayang.Jurnal Gervasi 1(1), 6170.

Wisudahwati, A.D. (2014). Metodologi Pembelajaran IPA. Yogyakarta: Bumi Aksara. 